\title{
Use of an external organic carbon source in the removal of nitrates in bio-sand filters (BSFs)
}

\author{
Crispen Mutsvangwa and Evans Matope \\ Department of Civil Engineering \& Surveying, Cape Peninsula University \\ of Technology, P.O. Box 1906, Bellville 7536, Cape Town, South Africa \\ Correspondence to: Crispen Mutsvangwa (mutsvangwac@cput.ac.za)
}

Received: 15 August 2017 - Discussion started: 18 August 2017

Revised: 8 October 2017 - Accepted: 10 October 2017 - Published: 16 November 2017

\begin{abstract}
Bio-sand filters (BSFs) are point-of-use (POU) potable water filtration systems commonly used in low-income communities at household level. The principle of operation is similar to that of a slow sand filter and the major difference is that they are operated intermittently at the POU. It is one of the emerging low-cost technologies which makes use of readily and locally available construction materials but is poor in the removal of nitrates. In order to enhance the removal of nitrates through denitrification, a modified BSF with ethanol as an external carbon source at $\mathrm{C} / \mathrm{N}$ ratios of 1.1 and 1.8 was investigated. In the absence of an external carbon source, the nitrate removal efficiency was $32 \%$, whilst removal efficiencies at $\mathrm{C} / \mathrm{N}$ ratios of 1.1 and 1.8 were 44 and $53 \%$ respectively. The inflow rate reduced significantly from an initial flow rate of 0.04 to $0.01 \mathrm{~m}^{3} \mathrm{~h}^{-1}$. The reduction in the inflow rate was mainly due to the growth of the biological layer on the filter media. The study showed that the use of an external carbon source like ethanol in bio-sand filtration enhances the removal of nitrates in potable water.
\end{abstract}

\section{Introduction}

Bios-sand filters (BSFs) are intermittent slow sand filters designed for household use and hence called point-of-use (POU) water filtration systems, with principal filtration mechanisms being physical, chemical and biological (Murphy et al., 2010). The biological mechanisms take place at the top layer, where a biological mat develops in the 50 to $100 \mathrm{~mm}$ of the media (CAWST, 2009). The biological layer acts both as a fine filter to remove small colloidal particles, dissolved impurities and at the same time immobilizes pathogens.

Although BSFs are now widely applied in the treatment of water at household level, few studies have been conducted on the removal of chemical contaminants. Current research in BSFs has mainly focused on the removal of pathogenic organisms like Escherichia coli (E. coli) and suspended solids (Elliott et al., 2008; Van Halem et al., 2009; Mwabi et al., 2012). One chemical of major concern is nitrate-nitrogen contamination $\left(\mathrm{NO}_{3}-\mathrm{N}\right)$ on surface and ground water as it poses serious health problems (Almasiri and Kaluarachchi,
2007). Methaemoglobinemia in infancy is related to nitrate ingestion resulting in low oxygen intake and consequently causing death (Craun et al., 1981; Aslan and Cakici, 2007). Furthermore, presence of nitrates in drinking water results in the formation of nitrosomines in the stomach, which are carcinogenic (Shuval and Gruener, 1977; Aslan and Cakici, 2007; Speijers and Fawell, 2011). Nitrate poisoning has been reported in livestock when concentrations exceeded $100 \mathrm{~m} \mathrm{~L}^{-1}$ (Tredoux et al., 2000) and other problems related to nitrate in drinking water are well documented in the literature (Moraes, 1996; Fan and Steinberg, 1996; Lin et al., 2002; Forman, 2004).

Main sources of $\mathrm{NO}_{3}-\mathrm{N}$ on surface waters and groundwater aquifers include use of agricultural fertilizers, animal waste disposal and wastewater effluents from conventional and on-site sanitation facilities. Water supply from highnitrate concentration environments needs some form of treatment or dilution with low-nitrate content water. The current design of conventional BSFs has been proved to be poor in the removal of nitrates (Heather et al., 2010; Mahlangu et al., 
2011; Kennedy et al., 2012). Physical and chemical methods such as ion-exchange, reverse osmosis, electro-dialysis, distillation, nanofiltration and activated carbon have been applied in the removal of nitrates from drinking water supplies (Schoeman and Steyn, 2003; Shaharudin et al., 2017). These methods are relatively expensive and show poor selectivity for nitrate removal with generation of brine, which is difficult to dispose of (Mohseni-Bandpi et al., 2013). Hence there is need to explore alternative technologies like biological denitrification which has been proved to be efficient in complete nitrate elimination and has the advantage of producing a harmless by-product $\left(\mathrm{N}_{2}\right)$. The pathway for nitrate removal by heterotrophic bacteria is nitrate $\rightarrow$ nitrite $\rightarrow$ nitric oxide $\rightarrow$ nitrous oxide $\rightarrow$ gaseous diatomic nitrogen:

$\mathrm{NO}_{3}^{-} \rightarrow \mathrm{NO}_{2}^{-} \rightarrow \mathrm{NO} \rightarrow \mathrm{N}_{2} \mathrm{O} \rightarrow \mathrm{N}_{2} \uparrow$.

The biological denitrification technology is based on the conventional theory that carbon is the limiting factor in the efficiency of biological denitrification. Heterotrophs utilize carbon from organic compounds like sugars, organic acids and amino acids as source of electrons rather than from inorganic compounds like carbon dioxide as is the case in autotrophic denitrification (Mohseni-Bandpi et al., 2013). Although autotrophic nitrate removal has the advantage of not requiring an organic carbon source, it is associated with slow growth rate of autotrophic bacteria and low nitrate removal rate (Mohseni-Bandpi et al., 2013).

Few studies have been conducted on the effectiveness of the BSFs in the removal of nitrates. In a study conducted in rural Cambodia by Heather et al. (2010), it was revealed that there was simultaneous nitrification and denitrification occurring in the BSFs. However, about $85 \%$ of the biofilters under the study did not meet the $\mathrm{WHO}$ guideline for $\mathrm{NO}_{3}-\mathrm{N}$ in the treated effluent. The study showed that denitrification was predominant when the inflow into the filter was from surface water, which could be due to the high organic carbon content. Kennedy et al. (2012) studied the effects of hydraulic loading on removal of nitrates in BSFs and the overall nitrate removal efficiency was low (16\%). Mahlangu et al. (2011) established that the conventional BSFs and the modified BSFs of zeolites (clinoptilote) have relatively low removal rates of nitrates $(37 \%)$. In the same study, other types of biofilters which include ceramic candle and bucket filters had poor rates of removal of nitrates ranging from 18 to $37 \%$ (Mahlangu et al., 2011). On certain occasions, the effluent concentration of $\mathrm{NO}_{3}-\mathrm{N}$ was even higher than in the unfiltered water, possibly due to desorption of previously adsorbed nitrates and nitrification. Research has also revealed that heterotrophic nitrifying microorganisms are key players in the nitrogen cycle and can increase the effluent concentration of $\mathrm{NO}_{3}-\mathrm{N}$ through cell lysis (Masahito et al., 2008).

Most sources of drinking water lack sufficient quantities of organic carbon for cell growth as well as for energy source for the heterotrophic bacteria (Mohseni-Bandpi et al., 2013). The organic carbon acts as both a source of cellular material for biological respiration and electron donor for dissimilatory nitrate reduction. Waters with low carbon content require an external carbon source for denitrification to take place under anoxic conditions and nitrate is converted to gaseous diatomic nitrogen.

A variety of external carbon sources like sucrose, ethanol, methanol and acetic acid have been applied in conventional slow sand filters to aid heterotrophic denitrification at $\mathrm{C} / \mathrm{N}$ ratios ranging from 1 to 2.5 (Callado, 2001; Gomez et al., 2000; Aslan and Cakici, 2007). The studies have shown considerable improvement levels in the denitrification process due to the recorded high nitrate removal efficiencies of about $90 \%$ (Green et al., 1994). Gomez et al. (2000) assayed the influence of sucrose, ethanol, methanol and ethyl alcohol in nitrate reductase in contaminated groundwater and showed very high removal rates with effluent concentrations ranging from 0 to $5 \mathrm{mgL}^{-1}$. Aslan and Cakici (2007) reported removal rate of $94 \%$ for nitrate in slow sand filters when acetic acid was used as a carbon source. Methanol is toxic due to some of the residual concentrations of carbonaceous compounds found in the effluent and produces an excessive growth of biomass (Stouthamer, 1992; Cherchi et al., 2009; Jensen and Darby, 2012). Sucrose and glucose have a tendency to form a biomass which increases turbidity in the final effluent. Acetic acid and ethanol are considered to be the most suitable carbon sources for removal of nitrate and no limits have been set in potable water (Ghararah, 1996). They are also cheaper, a concept inherent in the use of bio-sand filtration technology.

However, heterotrophic denitrification has not been investigated in BSFs except in the conventional slow sand filters. The aim of this study was to investigate the removal of $\mathrm{NO}_{3}-$ $\mathrm{N}$ in BSFs with ethanol as a carbon source and to establish the optimum carbon-to-nitrate $(\mathrm{C} / \mathrm{N})$ ratio for microbial activity which achieves maximum removal with minimum excess carbon in the effluent.

\section{Materials and methods}

Two BSFs were investigated at household level: one with an external carbon source (BSFC) to enhance the denitrification process at $\mathrm{C} / \mathrm{N}$ ratios of 1.1 and 1.8, and the other one without a carbon source (BSFW). Figure 1 shows the schematic diagram of the BSFs which were constructed. These two ratios were selected based on the optimum range of carbonto-nitrogen ratio which was established by Aslan and Cakici (2007), Gomez et al. (2000) and Callado (2001) for denitrification in slow sand filtration, which ranged from 1.08 to 2.5. The two BSFs were dosed with known concentrations of ammonium nitrate, which was the source of nitrate. 


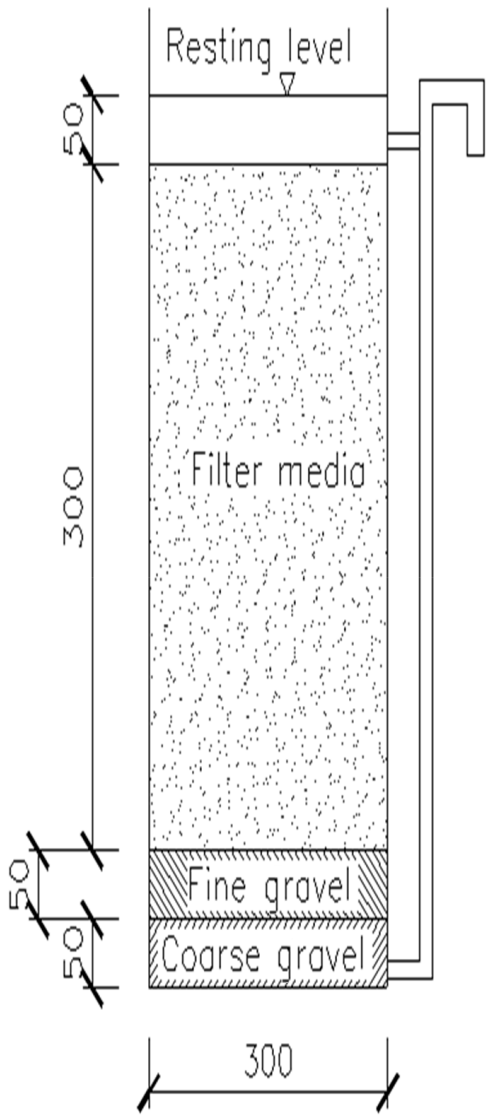

Figure 1. Schematic representation of the BSF (dimensions in $\mathrm{mm})$. The direction of filtration flow is from top to bottom of filter bed.

\subsection{Filter construction}

The two BSFs were constructed according to the Centre for Affordable Water and Sanitation Technology guidelines (CAWST, 2009). Plastic buckets $25 \mathrm{~mL}$ in volume were used and were packed with multi-media filter material. The multimedia filter bed consisted of fine sand of $0.3 \mathrm{~mm}$ diameter and $250 \mathrm{~mm}$ deep; sand of $0.95 \mathrm{~mm}$ diameter and $750 \mathrm{~mm}$ deep; gravel of $7 \mathrm{~mm}$ diameter and $50 \mathrm{~mm}$ deep. The South African National Standard (SANS 3001) was used to determine the particle size and grading in order to achieve the required particle size distribution of the filter media. Dewatering of the filter between charges is avoided by a vertical discharge tube that rises from 2 to $7 \mathrm{~cm}$ above the height of the filter media. The elevated outlet allows the media to remain saturated after a charge has been filtered and when water is no longer flowing from the outlet (Fig. 1). The design parameters of the filter are summarized in Table 1.

The filtration cycle of a biofilter is made up of resting time (6-24 h) and a maximum filtration time of about $2 \mathrm{~h}$ (Fewster et al., 2004). The biological treatment occurs during the resting time and after this period the filter bed is drained. In this study the raw surface water or untreated river water was fed into the filter once a day and the resting time and filtration time were 24 and $2 \mathrm{~h}$ respectively. The filtered water was collected in a $5 \mathrm{~L}$ vessel for laboratory analysis. The average inflow rate was measured from noting the start time of filtration and the time periods at which the level of the water in the receiving vessel changed by $1 \mathrm{~L}$.

The superficial velocity $\left(v_{\mathrm{s}}\right)$ is related to the surface area of the filter and is normally used in filtration computations and is also equivalent to the hydraulic surface loading divided by the surface area of the filter. For BSFs, the inflow rate is not constant since the water is only poured once for a filter cycle and hence the infiltration velocity decreases with time from the start to end of cycle.

\subsection{Nitrate and carbon source dosage}

An influent nitrate concentration of $25 \mathrm{mg} \mathrm{L}^{-1}$ was selected based on the guideline value of $11 \mathrm{mg} \mathrm{L}^{-1}$ in potable water and the average reported values of nitrates in surface- and groundwaters, which range between 0 and $18 \mathrm{mg} \mathrm{L}^{-1}$ (WHO, 2011). The raw river water had a low background concentration of nitrate ranging from 0.39 to $1.15 \mathrm{mg} \mathrm{L}^{-1}$. However, large parts of southern Africa have nitrate values often exceeding $50 \mathrm{mgL}^{-1}$ (Tredoux, 2004). A stock solution of ammonium nitrate $\left(\mathrm{NH}_{4} \mathrm{NO}_{3}\right)$ of concentration of $190 \mathrm{gL}^{-1}$ was dosed to both filters (BSFW and BSFC), and to achieve a dose of $25 \mathrm{mg} \mathrm{L}^{-1}$ in the $25 \mathrm{~L}$ filter volume, $3.33 \mathrm{~mL}$ of the stock solution was required. The ethanol was applied only to $\mathrm{BSFC}$ at $\mathrm{C} / \mathrm{N}$ ratios of 1.1 and 1.8. With a molar mass of $46 \mathrm{~g} \mathrm{~mol}^{-1}$ of ethanol $\left(\mathrm{C}_{2} \mathrm{H}_{5} \mathrm{OH}\right)$ the carbon equivalent in the ethanol was $24 \mathrm{~g} \mathrm{~mol}^{-1}(52.2 \%)$. Therefore, at a nitrate dose of $25 \mathrm{mg} \mathrm{L}^{-1}$ and $\mathrm{C} / \mathrm{N}$ ratio of 1.1 the dosage of carbon as ethanol in a $25 \mathrm{~L} \mathrm{BSF}$ was $7.45 \mathrm{~mL}$ of carbon as ethanol. Similarly, at C / N ratio of 1.8, the required dose of carbon as ethanol was $12.1 \mathrm{~mL}$.

The surface loading of $\mathrm{NO}_{3}-\mathrm{N}$ was calculated by multiply the concentration of nitrate with the superficial velocity $\left(\mathrm{g} \mathrm{m}^{-2} \mathrm{~d}\right)$ and the denitrification rate was computed as

$R_{\mathrm{dn}}=\frac{1}{t}\left(C_{\mathrm{in}}-C_{\mathrm{out}}\right)$

where $R_{\mathrm{dn}}$ is denitrification rate $\left(\mathrm{ML}^{-3} \mathrm{~T}\right), C_{\mathrm{in}}$ is influent nitrate $\left(\mathrm{ML}^{-3}\right)$ and $C_{\text {out }}$ is effluent nitrate $\left(\mathrm{ML}^{-3}\right)$.

\subsection{Filter maturation}

The denitrification process in BSFs is biological and takes place under a fixed film growth process whereby the bacteria develop on the surface of the sand media. For the smooth operation of the BSF, the water level was maintained at $50 \mathrm{~mm}$ above the fine sand. The maturation period for the full development of the biological layer and acclimatizing of the microorganisms to ethanol and $\mathrm{NO}_{3}-\mathrm{N}$ environment was 3 weeks. The biological layer typically takes 20 to 30 days 
Table 1. Summary of the design values used for the two filters (BSFW and BSFC).

\begin{tabular}{|c|c|c|c|c|}
\hline Design parameter & Unit & $\begin{array}{l}\text { Recommended } \\
\text { value }\end{array}$ & Reference & $\begin{array}{l}\text { Applied } \\
\text { value }\end{array}$ \\
\hline Media depth & $\mathrm{m}$ & $0.3-0.5$ & CAWST (2009); Kubare and Haarhoff (2010) & 0.3 \\
\hline Supernatant depth & $\mathrm{mm}$ & 50 & $\begin{array}{l}\text { Lukacs (2002); Duke et al. (2006); CAWST } \\
\text { (2009) }\end{array}$ & 50 \\
\hline Surface area & $\mathrm{m}^{2}$ & 0.06 & CAWST (2009) & 0.071 \\
\hline Effective size & $\mathrm{mm}$ & $0.15-0.40$ & CAWST (2009), Manz et al. (1993) & 0.35 \\
\hline Coefficient of uniformity & - & 1.5 to 3 & Elliot et al. (2008); Manz et al. (1993); & 2.64 \\
\hline Filtration velocity (in clean filter bed) & $\mathrm{mh}^{-1}$ & 0.10 to 0.6 & $\begin{array}{l}\text { Kubare and Haarhoff (2010); Elliot et } \\
\text { al. (2008); }\end{array}$ & $0.17-0.63$ \\
\hline Inflow rate & $\mathrm{m}^{3} \mathrm{~h}^{-1}$ & 0.03 to 0.04 & CAWST (2009) & 0.04 \\
\hline
\end{tabular}

to develop to maturity in a new filter depending on the quality of the inlet water (CAWST, 2009; Mahlangu et al., 2011). The operating temperatures of the filters varied between 19 and $20^{\circ} \mathrm{C}$ and were not controlled, in order to simulate the actual operating conditions of a BSF at household level.

\subsection{Sample collection and analysis}

Sampling bottles were washed with distilled water before and after sampling. The samples were collected at the inlet and outlet of the two BSFs in $500 \mathrm{~mL}$ Erlenmeyer flasks and stored in a refrigerator at $4{ }^{\circ} \mathrm{C}$ and analysed within $1 \mathrm{~h}$. The frequency of sample collection was once a week after the $12 \mathrm{~h}$ resting time.

The $\mathrm{pH}$ and dissolved oxygen (DO) were measured using a pH meter, model HACH HQ30D (FLEXI model). The instrument was calibrated and measurements conducted in accordance with the standard method. The nitrate was measured by Spectroquant nitrate photometrical test method using Merck spectrophotometer PHARO100 and the results were reported as $\mathrm{NO}_{3}-\mathrm{N}$ in $\mathrm{mg} \mathrm{L}^{-1}$. The carbon source which was ethanol was measured as chemical oxygen demand (COD) by the MERCK Spectroquant TR 320 digester (Spectroquant COD cell test method). The samples were digested in tubes containing a mixture of chromic and sulfuric acid with silver sulfate as a catalyst. After digestion samples were cooled and read on the Spectroquant PHARO100 spectrophotometer. The COD test was carried out mainly to determine the amount of ethanol as a carbon source in the source water before and after the filtration process.

\section{Results and discussions}

\subsection{Flow rates}

Initial flow rates in the control filter BSFW started from $0.04 \mathrm{~m}^{3} \mathrm{~h}^{-1}$ and declined to $0.03 \mathrm{~m}^{3} \mathrm{~h}^{-1}$ by the end of the experiment. In BSFC which received the carbon source the flow rate reduced from 0.04 to $0.01 \mathrm{~m}^{3} \mathrm{~h}^{-1}$ (Fig. 2). The reduction in flow rates was comparable to studies conducted on BSFs by Kubare and Haarhoff (2010) and Kennedy et al. (2012). The decline in the filtration rate was due to filter clogging and was substantial when the biological layer was fully mature. The reduction in the flow rate was more pronounced in the filter dosed with an external carbon source (BSFC) compared to one without carbon (BSFW). Therefore, there was more growth of the biomass in the biofilter with an external carbon source due to the favourable environment conducive for growth of heterotrophic bacteria. Conventional surface cleaning will not remove the biomass at the bottom layers. Consequently, a household would require more filters to meet the daily water demand as well as increasing the resting period in BSFC to reduce excessive growth of biomass. Overall, the filtration velocity ranged from 0.17 to $0.63 \mathrm{~m} \mathrm{~h}^{-1}$ and typical filtration rates for BSF range from 0.16 to $1.1 \mathrm{~m} \mathrm{~h}^{-1}$ (Elliot et al., 2008; Kubare and Haarhoff, 2010).

\subsection{Changes in $\mathrm{pH}$ and $\mathrm{DO}$}

The $\mathrm{pH}$ and DO are important physicochemical parameters in the removal of nitrates in BSFs. There was no significant change in the $\mathrm{pH}$ of the influent and effluent water for both filters (BSFW and BSFC). Overall, there was a slight decrease in $\mathrm{pH}$ from 8.6 to 6.8 and such a $\mathrm{pH}$ range would favour the denitrification process since maximum denitrification rates are achieved at $\mathrm{pH}$ range of 7 to 8.5 (Wang et al., 1995), whereas $\mathrm{pH}$ values smaller than 6 and larger than 8.5 would result in a sharp decrease in the denitrification activities (Drtil et al., 1995). The slight decrease in $\mathrm{pH}$ could be due to nitrification and aerobic respiration at the top layer of the filter due to availability of oxygen and this phenomenon was also confirmed by Heather et al. (2010) and MangouaAllali et al. (2012). Nitrification is obligatorily coupled to oxygen consumption and has an effect on the decrease in alkalinity. Such a decrease in alkalinity might cause a decrease in $\mathrm{pH}$ because an acidic nitrite formation results in a drop in $\mathrm{pH}$. Thus, if the buffer capacity of the system is weak, the $\mathrm{pH}$ might drop well below 6.7 (Habboub, 2007). 


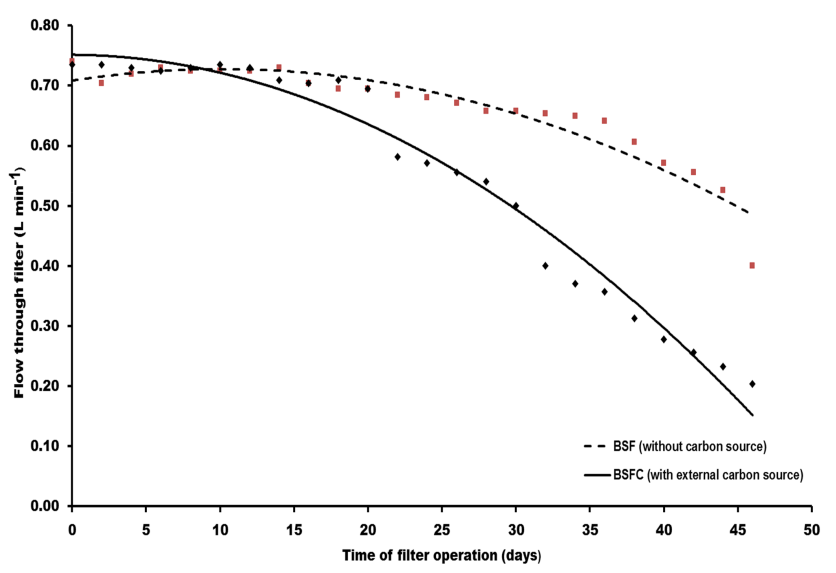

Figure 2. Variation in flow rates in the filters with and without carbon source.

However, $\mathrm{pH}$ may increase during denitrification because the reduction of nitrate to gaseous nitrogen with organic substrate as an electron donor results in the production of carbon dioxide and oxygen hydroxide $\left(\mathrm{OH}^{-}\right)$, which may react to form a bicarbonate $\left(\mathrm{HCO}_{3}^{-}\right)$and carbonate $\left(\mathrm{CO}_{3}^{2-}\right)$ (Drtil et al., 1995; Wang et al., 1995). With regard to water quality guidelines, the $\mathrm{pH}$ values were within the acceptable South African guideline limits of 5.0 to 9.7 (SANS 241-2, 2015).

The overall reduction of DO in the filter with an external carbon source was $65 \%$ with average inflow and outflow concentrations of 8.23 and $2.94 \mathrm{mg} \mathrm{L}^{-1}$ respectively.

DO concentration is influenced by a number of factors including water temperature, organic matter, salinity and atmospheric pressure. The operating temperature of the filters was between 19 and $20^{\circ} \mathrm{C}$ and the measured DO values are typical at such temperatures. Furthermore, the water which was used was raw river water, and the DO can range between 0 and $18 \mathrm{mg} \mathrm{L}^{-1}$ in such waters depending on the level of pollution. However, the reduction in dissolved oxygen was less in the filter without an external carbon source $(50 \%)$. The reduction in the DO is due to the oxygen demand by aerobic and nitrifying bacteria at the top layer of the filter bed.

\subsection{Nitrate removal rates}

The nitrate removal mechanisms during heterotrophic denitrification are bacterial respiration and bacterial synthesis (Mohseni-Bandpi et al., 2013). The denitrification will take place at the bottom of the filter bed where there is less oxygen (anoxic conditions). William and Beresford (1998) concluded that nitrification and denitrification happen simultaneously in zones where there are short distances between the aerobic and anaerobic zones. The same scenario is depicted in BSFs due to the short filtration length of approximately 0.3-0.5 m (Elliot et al., 2008; CAWST, 2009).

Heterotrophic bacteria need organic carbon as the electron donor and as the source of carbon, whilst getting their oxy- gen by removing bound oxygen from nitrate $\left(\mathrm{NO}_{3}^{-}\right)$which is in the water being treated. The nitrate acts as the electron acceptor. As a result of this process, the removal rate of nitrates in the filter without external carbon source (BSFW) was $30 \% \pm 0.04$ (Table 2) and Mahlangu et al. (2011) reported a rate of $37 \%$ in similar filters. In the filter with an external carbon source (BSFC) the nitrate removal rate was $44 \% \pm 0.03$ at $\mathrm{C} / \mathrm{N}$ ratio of 1.1 and $53 \% \pm 0.03$ at $\mathrm{C} / \mathrm{N}$ ratio of 1.8. Overall, the nitrate removal rate was higher with the use of an external carbon source at higher $\mathrm{C} / \mathrm{N}$ ratio of 1.8. The reason for this is that carbon is the limiting factor in denitrification since heterotrophic bacteria need organic carbon as the electron donor and as the source of carbon. Therefore, a higher carbon content will result in a higher nitrate removal rate. However, the effluent nitrate concentration of between 16 and $19 \mathrm{mg} \mathrm{L}^{-1}$ was still above the recommended guideline values for potable water.

The failure to achieve effluent nitrate guideline values even though $\mathrm{pH}$ was optimum could be due to high DO. Optimum denitrification occurs under anoxic conditions when oxygen levels are depleted (low redox) and nitrate becomes the primary oxygen source for heterotrophic bacteria. In general, it has been observed that a DO concentration of more than $0.2 \mathrm{mgL}^{-1}$ reduces the rate of denitrification significantly (Jorgensen and Sorensen, 1988). High levels of DO were recorded ranging between 2.9 and $8.2 \mathrm{mgL}^{-1}$ - higher than the optimum values for denitrification.

Reducing the DO concentration in a BSF will enhance the nitrate removal efficiency but will compromise the aerobic microbial activity at the top layer. A feasible alternative would be to increase the filter depth so as to create an anoxic zone at the bottom or to increase the resting period of the filter. BSFs are designed with a filtration time of $2 \mathrm{~h}$ and resting period of 12 to $24 \mathrm{~h}$ (CAWST, 2009; Elliott et al., 2008). The resting time provides the contact time for microbial removal and denitrification processes and thus a long resting time is desirable from that perspective. However, too long a resting period may reduce the viability of the biological layer because the survival of the microorganisms relies on the periodic inflow of source water for nutrients (Baumgartner et al., 2007). Additionally, too long a resting period will reduce the water production rate and thus fail to satisfy household water requirements. Therefore, careful selection of the resting period is vital in order to balance these competing objectives. In this study a resting time of $12 \mathrm{~h}$ was used and nitrate concentrations measured during this period showed a rapid removal rate during the first $1.5 \mathrm{~h}$ and no significant removal thereafter (Fig. 3). Therefore, increasing the resting period by more than $12 \mathrm{~h}$ will not have any significant effect on nitrate removal. Results for the entire operational period indicate low removal at the beginning (40\%). Thereafter the rate increased to $53 \%$. This illustrates the importance of maturation period. The variation in nitrate concentrations for the entire operational period is shown in Fig. 4. 
Table 2. Nitrate removal efficiency at $\mathrm{C} / \mathrm{N}=1.1 ; \mathrm{C} / \mathrm{N}=1.8$ and at influent nitrate concentration of $25 \mathrm{mgL}^{-1}$.

\begin{tabular}{|c|c|c|c|c|c|c|}
\hline \multirow[b]{2}{*}{$\begin{array}{l}\text { Sampling interval } \\
\text { (days) }\end{array}$} & \multicolumn{2}{|c|}{ BSFW (without external carbon) } & \multicolumn{2}{|c|}{$\mathrm{BSFC}$ at $\mathrm{C} / \mathrm{N}=1.1$} & \multicolumn{2}{|c|}{$\mathrm{BSFC}$ at $\mathrm{C} / \mathrm{N}=1.8$} \\
\hline & $\begin{array}{l}\text { Effluent nitrate } \\
\qquad\left(\mathrm{mg} \mathrm{L}^{-1}\right)\end{array}$ & $\begin{array}{r}\text { Removal } \\
\text { efficiency }(\%)\end{array}$ & $\begin{array}{l}\text { Effluent nitrate } \\
\qquad\left(\mathrm{mgL}^{-1}\right)\end{array}$ & $\begin{array}{r}\text { Removal } \\
\text { efficiency }(\%)\end{array}$ & $\begin{array}{l}\text { Effluent nitrate } \\
\qquad\left(\mathrm{mg} \mathrm{L}^{-1}\right)\end{array}$ & $\begin{array}{r}\text { Removal } \\
\text { efficiency }(\%)\end{array}$ \\
\hline 1 & 19.21 & 23 & 15.55 & 38 & 14.21 & 43 \\
\hline 2 & 19.00 & 24 & 14.95 & 40 & 13.08 & 48 \\
\hline 5 & 18.75 & 25 & 14.90 & 40 & 13.01 & 48 \\
\hline 7 & 16.25 & 35 & 14.81 & 41 & 12.85 & 49 \\
\hline 9 & 16.50 & 34 & 14.74 & 41 & 12.81 & 49 \\
\hline 12 & 17.00 & 32 & 14.61 & 42 & 12.75 & 49 \\
\hline 14 & 17.50 & 30 & 14.55 & 42 & 12.73 & 49 \\
\hline 17 & 16.00 & 36 & 14.50 & 44 & 12.70 & 49 \\
\hline 20 & 16.32 & 35 & 14.50 & 42 & 11.75 & 53 \\
\hline 22 & 16.42 & 34 & 14.50 & 42 & 11.60 & 54 \\
\hline 24 & 16.30 & 35 & 13.50 & 46 & 11.50 & 54 \\
\hline 27 & 15.64 & 37 & 13.00 & 48 & 11.75 & 53 \\
\hline 29 & 15.73 & 37 & 12.65 & 49 & 11.90 & 52 \\
\hline
\end{tabular}

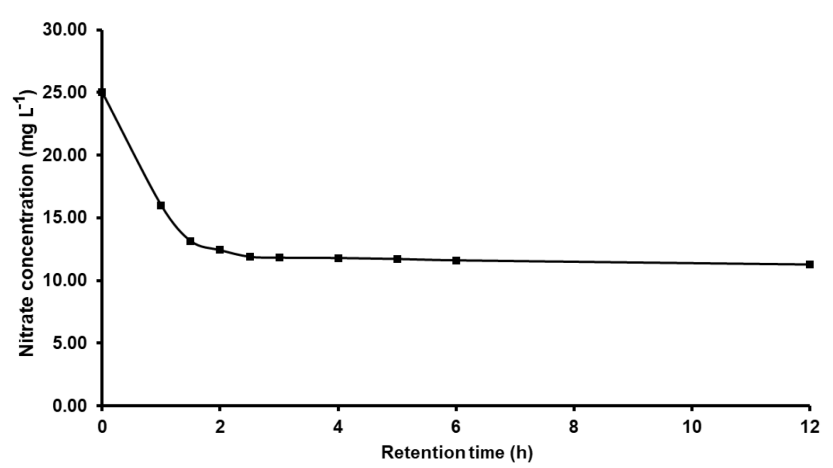

Figure 3. Reduction of nitrate relative to resting period in the filter with an external carbon source. Values of the nitrate are the average of the $\mathrm{C} / \mathrm{N}$ ratio of 1.1 and 1.8 .

The average denitrification rates for BSFW and BSFC were 3.66 and $5.44 \mathrm{~g} \mathrm{NO}_{3}-\mathrm{N} \mathrm{m}^{-3}$ days respectively and these rates are lower than those reported by Aslan and Cakici (2007) in slow sand filters (ranging between 8.1 and $29.2 \mathrm{~g} \mathrm{NO}_{3}-\mathrm{N} \mathrm{m}^{-3}$ days at filtration rates between 0.015 and $\left.0.06 \mathrm{mh}^{-1}\right)$.

\subsection{Residual COD in effluent}

The residual ethanol measured as COD in filters with an external carbon source varied between $25 \mathrm{mg}$ and $36 \mathrm{mg} \mathrm{L}^{-1}$. Overall, the removal efficiency of COD at $\mathrm{C} / \mathrm{N}$ ratio of 1.1 and 1.8 was 89 and $91 \%$ respectively (Table 3 ).

There was rapid COD removal in the first $2 \mathrm{~h}$. The rate stabilizes as the resting period increases and hence there is no significant benefit in longer resting periods. The same trend is seen for nitrate removal, which suggests that the denitrification process takes place in the first $2 \mathrm{~h}$ when the COD is

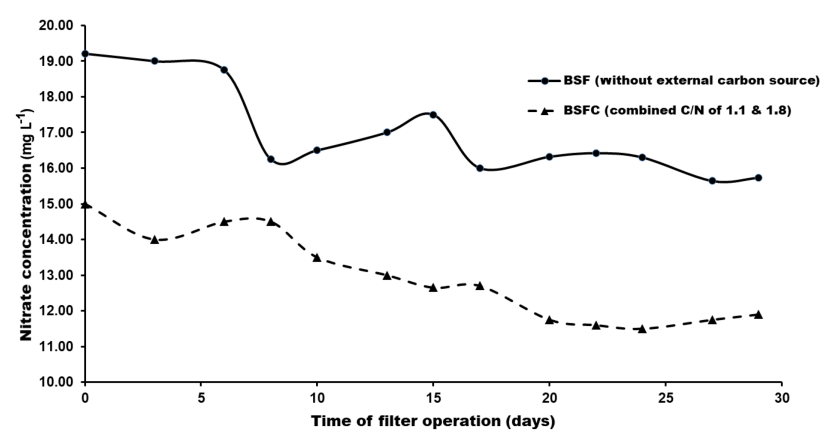

Figure 4. Variation in nitrate concentrations for the entire operational period.

utilized in the process. However, the COD concentrations in the effluent were higher than the guideline values, and such high levels of COD concentrations can be toxic to human health and increase disinfection by-product formation potential. This represents a major health challenge in the use of an external carbon source for the removal of nitrates in potable water and there is a need to explore post-treatment methods to remove the residual carbon in BSFs.

\section{Conclusions}

Bio-sand filtration enhanced by ethanol as an external carbon source has potential in the removal of nitrates in potable water at household level. The average nitrate removal efficiency in BSFs with ethanol as an external carbon source at $\mathrm{C} / \mathrm{N}$ ratios of 1.1 and 1.8 was $44 \% \pm 0.03$ and $53 \% \pm 0.03$ respectively. Although the nitrate concentration levels in effluent exceeded the recommended guidelines, the technology is capable of limiting nitrate in drinking water. Increasing the resting period more that than $12 \mathrm{~h}$ will not have any signifi- 
Table 3. COD removal efficiency at $\mathrm{C} / \mathrm{N}=1$ and $\mathrm{C} / \mathrm{N}=1.8$ and influent COD of 233.52 and $382.12 \mathrm{mgL}^{-1}$ respectively.

\begin{tabular}{lccccc}
\hline $\begin{array}{l}\text { Sampling interval } \\
\text { (days) }\end{array}$ & $\begin{array}{c}\text { Effluent COD } \\
\left(\mathrm{mgL}^{-1}\right)\end{array}$ & $\begin{array}{c}\text { COD removal } \\
\text { efficiency (\%) }\end{array}$ & & $\begin{array}{c}\text { Effluent COD } \\
\left(\mathrm{mgL}^{-1}\right)\end{array}$ & $\begin{array}{c}\text { COD removal } \\
\text { efficiency (\%) }\end{array}$ \\
\cline { 2 - 3 } \cline { 5 - 6 } & \multicolumn{2}{c}{$\mathrm{C} / \mathrm{N}=1.1$} & & & \multicolumn{2}{c}{$\mathrm{C} / \mathrm{N}=1.8$} \\
\hline 1 & 26.85 & 88.50 & & 34.62 & 90.94 \\
2 & 25.30 & 89.17 & & 35.17 & 90.80 \\
5 & 25.61 & 89.03 & & 35.98 & 90.58 \\
7 & 23.98 & 89.73 & & 34.48 & 90.98 \\
9 & 24.77 & 89.39 & & 35.96 & 90.59 \\
12 & 25.10 & 89.25 & & 34.84 & 90.88 \\
14 & 26.36 & 88.71 & & 34.46 & 90.98 \\
17 & 24.67 & 89.44 & & 35.54 & 90.70 \\
20 & 26.46 & 88.67 & & 36.10 & 90.55 \\
22 & 26.70 & 88.57 & & 35.86 & 90.62 \\
24 & 26.55 & 88.63 & & 35.42 & 90.73 \\
27 & 26.48 & 88.66 & 35.40 & 90.74 \\
29 & 26.22 & 88.77 & 35.18 & 90.79 \\
\hline
\end{tabular}

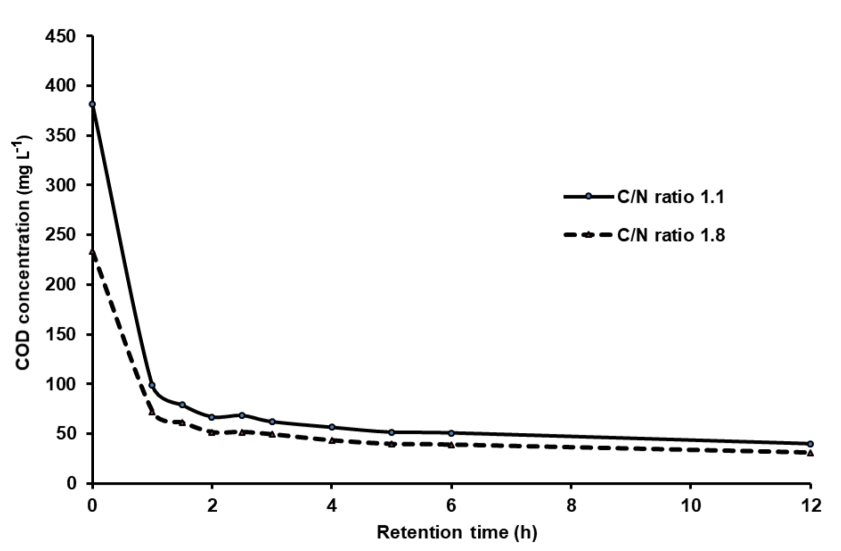

Figure 5. Reduction of COD relative to resting period in the filter with an external carbon source.

cance in the nitrate and COD removal rates since these two processes take place in the first $2 \mathrm{~h}$. DO concentration in the effluent reduced significantly due to aerobic oxidation and nitrification which took place simultaneously on the upper layer of the filter. The reduced DO low levels promoted heterotrophic denitrification at the bottom of the BSFs. However, the DO levels were still above for optimum values for denitrification. Also, the residual COD concentrations were above the water quality guidelines.

The flow rates reduced with time throughout the experiment due to the growth of the biological layer and clogging of the filter media. As a result, the yield of the biofilter was reduced. The flow rate reduction was higher in the filter with an external carbon source and was substantial when the biological layer was fully mature. Overall, the study suggests that there is high potential in the use of POU filters enhanced with an external carbon source for the removal of nitrates through heterotrophic denitrification. The major challenge in relation to the use of an external carbon source is the high residual COD concentration, which may pose a health risk.

Data availability. The data set is available in the Supplement.

The Supplement related to this article is available online at https://doi.org/10.5194/dwes-10-119-2017-supplement.

Competing interests. The authors declare that they have no conflict of interest.

Edited by: Ran Shang

Reviewed by: Nor Amani Filzah Mohd Kamil and two anonymous referees

\section{References}

Almasiri, M. N. and Kaluarachchi, J. J.: Modelling nitrate contamination of groundwater in agricultural watersheds, J. Hydrol., 343, 211-229, 2007.

Aslan, S. and Cakici, H.: Biological denitrification of drinking water in slow sand filter, J. Hazard. Mater., 148, 253-258, 2007.

Baumgartner, J., Murcott, S., and Ezzati, M.: Reconsidering appropriate technology: The effects of operating conditions on the bacterial removal performance of two household drinking water filter systems, J. Environ. Res. Lett., 2, 1-6, 2007.

Callado, N. H.: Anaerobic-aerobic SBR system treating synthetic substrate simulating domestic sewage, PhD Thesis, University of Escola de Engenharia de São Carlos, São Paulo, 2001.

CAWST: Biosand Filter: Manual for Design, Construction, Installation and Maintenance; Centre for Affordable Water 
and Sanitation Technology, Calgary, Canada, available at: http://www.cawst.org/assets/File/Biosand_Filter_\%20Manual_ Version_1 (last access: 10 July 2016), 2009.

Cherchi, C., Onnis-Hayden, A., El-Shawabkeh, I., and Gu, A. Z.: Implication of using different carbon sources for denitrification in wastewater treatments, J. Water Environ. Res., 11, 788-799, 2009.

Craun, G. F., Greathouse, D. G., and Gunderson, D. H.: Methaemoglobin levels in young children consuming high nitrate well water in the United States, J. Int. J. Epidemiol., 10, 309-317, 1981.

Drtil, M., Nemeth, P., Kucman, K., Bodik, I., and Kasperek, V.: Acidobasic balances in the course of heterotrophic denitrification, J. Water. Res., 29, 1353-1360, 1995.

Duke, W. D., Nordin, R. N., Baker, D., and Mazumder, A.: The use and performance of BioSand filters in the Artibonite Valley of Haiti: A field study of 107 households, J. Rur. Rem. Health, 6, 570-585, 2006.

Elliott, M. A., Stauber, C. E., Koksal, F., DiGiano, F. A., and Sobsey, M. D.: Reductions of E-coli, echovirus type 12 and bacteriophages in an intermittently operated household-scale slow sand filter, J. Water. Res., 42, 2662-2670, 2008.

Fan, A. M. and Steinberg, V. E.: Health implications of nitrate and nitrite in drinking water: An update on methaemoglobinemia occurrence and reproductive and developmental toxicity, J. Regul. Toxicol. Pharm., 23, 35-43, 1996.

Fewster, E., Mol, A., and Wiessent-Brandsma, C.: The long term sustainability of household biosand filtration, 30th WEDC International Conference, Vientiane, Laos, 2004.

Forman, D.: Commentary: Nitrites, nitrates and nitrosation as causes of brain cancer in children: epidemiological challenge, J. Int. Epidemiol., 33, 1216-1218, 2004.

Ghararah, Z. H. A.: Biological denitrification of high nitrate water: Influence of type of carbon source and nitrate loading, J. Environ. Sci. Health Part A, 11, 1651-1668, 1996.

Gomez, M. A., Gonzalez-Lopez, J., and Hontoria-Garcia, E.: Influence of carbon source on nitrate removal of contaminated groundwater in denitrifying submerged filter, J. Hazard. Mater., B80, 69-80, 2000.

Green, M., Tarre, S., Schnizer, M., Bogdan, B., Armon, R., and Shele, G.: Groundwater denitrification using an upflow sludge blanket reactor, J. Water Res., 28, 631-637, 1994.

Habboub, W. Y.: Denitrification of groundwater using sand filter, MSc Thesis, University of Gaza, Faculty of Engineering Water Resources Management, Palestine, 2007.

Heather, M. M., Edward, A. M., and Khosrow, F.: Nitrification, denitrification and ammonification in point-of-use biosand filters in rural Cambodia, J. Water Health., 8, 803-817, 2010.

Jensen, V. B. and Darby, J. L.: Drinking Water Treatment for Nitrate, Technical Report 6, California, University of California, Davis, USA, 2012.

Jorgensen, S. K. and Sorensen, J.: Two annual maxima of nitrate reduction and denitrification in estuarine sediment, Mar. Ecol., Prog. Ser., 48, 147-154, 1988.

Kennedy, T. J., Hernandez, E. A., Morse, A. N., and Anderson, T. A.: Hydraulic Loading Rate Effect on Removal Rates in a Biosand Filter: A Pilot Study of Three Conditions, J. Water Air Soil Pollut., 223, 4527-4537, 2012.
Kubare, M. and Haarhoff, J.: 2010 Rational design of domestic biosand filters, J. Water Supply Res. T., 59, 1-15, 2010.

Lin, Y. F., Jing, S. R., Wang, T. W., and Lee, D.Y.: Effects of macrophytes and external carbon sources on nitrate removal from groundwater in constructed wetlands, J. Environ. Pollut., 119, 413-420, 2002.

Lukacs, H.: From design to implementation: Innovative slow sand filtration for use in developing countries, MEng Thesis, Civil and Environmental Engineering Department, Massachusetts Institute of Technology, 2002.

Mahlangu, T. O., Mpenyana-Monyatsi, L., Momba, M. N. B., and Mamba, B. B.: A simplified cost effective biosand filter (BSFZ) for removal of chemical contaminants from water, J. Chem. Eng. Mater. Sci., 2, 158-167, 2011.

Mangoua-Allali, A. L. C., Coulibaly, L., Ouattara, J. M. P., and Gourene, G.: Implementation of biosand filters in rural area for drinking water production, J. Afr. Food Sci., 6, 574-582, 2012.

Manz, D. H., Buzunis, B., and Morales, C.: Final report on the Nicaragua household water supply and testing project, Division of International Development, University of Calgary, Calgary, AB, Canada, 1993.

Masahito, H., Kanako, T., and Masanori, S.: Various players in the Nitrogen Cycle: Diversity and functions of the microorganisms involved in nitrification and denitrification, J. Soil Sci. Plant Nutri., 54, 33-45, 2008.

Mohseni-Bandpi, A., Elliott, D. J., and Zazouli, M. A.: Biological nitrate removal processes from drinking water supply, J. Rev. Environ. Health Sci. Eng., 11, 35, https://doi.org/10.1186/2052336X-11-35, 2013.

Moraes, L. R.: Health impact of drainage and sewerage in poor urban areas in Salvador, Brazil. Department of Epidemiology and Population Sciences, London School of Hygiene and Tropical Medicine University of London, 1996.

Murphy, H. M., McBean, E. A., and Farahbakhsh, K.: Nitrification, denitrification and ammonification in point-of-use biosand filters in rural Cambodia, J. Water Health., 8, 803-817, 2010.

Mwabi, J. K., Mamba, B. B., and Momba, M. G.: Removal of Escherichia coli and Faecal Coliforms from surface water and groundwater by household water treatment devices: A sustainable solution for improving water quality in rural communities of the Southern African Development Community Region, J. Environ. Res. Public Health, 9, 139-170, 2012.

SANS 241-2: South African National Standard, Drinking Water, SABS Standard Division, Pretoria, South Africa, 2015.

SANS 3001: South African National Standard, Civil Engineering Test Methods, SABS Standard Division, Pretoria, South Africa, 2015.

Schoeman, J. J. and Steyn, A.: Nitrate removal with reverse osmosis in a rural area in South Africa, J. Desalination, 155, 15-26, 2003.

Shaharudin, N., Suradi, N., and Kamil, N. A. F.: Measurement of water quality parameters before and after maintenance service in water filter system, in: Proceedings of MATEC Web Conference, 103, EDP Sciences, 2017.

Shuval, H. I. and Gruener, N.: Infant methemoglobinaemia and other health effects of nitrates in drinking water, J. Prog. Water Technol., 8, 183-193, 1977.

Speijers, G. J. A. and Fawell, J. K.: Nitrate and nitrite in drinkingwater, background document for development of WHO Guidelines for Drinking-water Quality, WHO, 2011. 
Stouthamer, A.: Metabolic pathways in paracoccus denitrificans and closely related bacteria in relation to the phylogeny of prokaryotes, J. Antonie Van Leeuwenhoek, 11, 1-33, 1992.

Tredoux, G. J. A.: Nitrate and associated hazard quantification and strategies for protection of rural water supplies, Water Research Commission, South Africa, 2004.

Tredoux, G., Talma, A. S., and Engelbrecht, J. F.: The Increasing nitrate hazard in groundwater in rural areas, WISA 2000 Biennial Conference, Sun City, South Africa, 2000.

Van Halem, D. S., Van Der Laan, H., Heijman, S. G. J., Van Dijk, J. C., and Amy, G. L.: Assessing the sustainability of the silverimpregnated ceramic pot filter for low-cost household drinking water treatment, J. Phys. Chem. Earth., 34, 36-42, 2009.
Wang, J. H., Bellzis, B. C., and Lewandwoski, G. A.: Fundamental de-nitrification kinetic studies with Pseudomonas denitrificans, J. Biotechnol. Bioeng., 5, 26-41, 1995.

WHO: Nitrate and nitrite in drinking water, 4th Edition, World Health Organisation, Geneva, Switzerland, available at: http:// www.who.int/watersanitation_health/dwq/chemicals/nitrate.pdf (last access: 11 November 2017), 2011.

William, S. C. and Beresford, J.: The effect of anaerobic zone mixing on the performance of a three-stage Bardenpho plant, J. Water Sci. Technol., 38, 55-62, 1998. 